\title{
Strategic fiscal interaction among OECD countries
}

\author{
Pantelis Kammas
}

\section{EERI Research Paper Series No 11/2009}

ISSN: 2031-4892

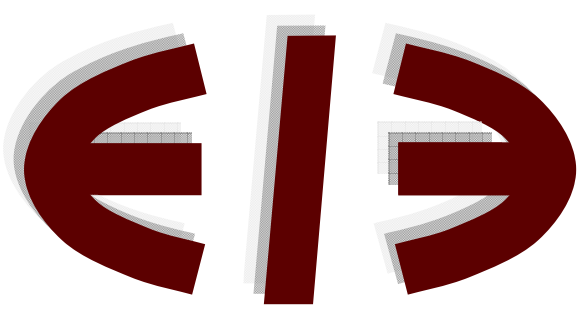

\section{EERI}

Economics and Econometrics Research Institute Avenue de Beaulieu 1160 Brussels

Belgium

Tel: +322 2993523

Fax: +322 2993523

www.eeri.eu 


\title{
Strategic fiscal interaction among OECD countries
}

\author{
by \\ Pantelis Kammas ${ }^{\mathrm{a}}$ \\ ${ }^{a}$ Department of Economics, University of Ioannina, P.O. Box 1186, 45110 Ioannina, Greece. \\ Email: kammas@cc.uoi.gr
}

March 24, 2009

\begin{abstract}
This paper investigates whether OECD countries compete with each other for mobile factors by using various fiscal (tax-spending) policy instruments. We use a panel dataset of 20 OECD countries over the 1982-2000 period. There is evidence that international capital inflows (FDI) are affected by fiscal policy at home and abroad. Also, there is evidence of fiscal competition for mobile factors which takes place via capital tax rates. More precisely, we find that domestic capital tax rates react: (i) positively to changes in capital tax rates and (ii) negatively to changes in public investment spending in neighbouring countries. In contrast, evidence of such a strategic interdependence over public investment spending decisions is not established.
\end{abstract}

JEL: F02, H2, H4.

Keywords: capital mobility; tax competition; welfare

Acknowledgments: I am grateful to Konstantinos Angelopoulos and Apostolis Philippopoulos for valuable suggestions and discussions. I have benefited from comments by Antonis Adam, Manthos Delis, George Economides, Nikos Tsakiris. The research presented in this paper was financially supported by the Greek Ministry of Education and the European Union under the "Iraklitos" research fellowship program 


\section{Introduction}

Policy interdependence across countries is the cornerstone of recent policy debate focusing on fiscal competition among national governments. In the tax competition literature, which is the most popular branch of research in this area, national governments cut their tax rates in an attempt to attract mobile factors (see e.g. Wildasin, 1988; Persson and Tabellini, 1992). ${ }^{1}$ Similar incentives may be present in government spending decisions (see e.g. Keen and Marchand 1997; BayindirUpmann, 1998; Fuest, 1995). In this case, national governments increase some categories of spending, like public investment, again in an attempt to attract mobile factors. $^{2}$ All these are examples of non-cooperative, prisoner's dilemma situations.

There is empirical support for these predictions. ${ }^{3}$ Focusing on OECD economies, Devereux et al. (2008) provide evidence that countries do choose their tax rates on corporate profits in a strategic way. The same result is also shared by Besley et al. (2001), who estimate a wide set of tax reaction functions for OECD countries and by Cassette and Patty (2008), who investigate potential existence of strategic interactions between the former EU15 countries and the countries of Central and Eastern Europe regarding corporate tax rates. Redoano (2007), focusing on a set of fiscal variables both on revenue and expenditure sides, concludes that countries interact over capital

\footnotetext{
${ }^{1}$ The possibility that competition across national jurisdictions in order to attract capital results in inefficiently low tax rates and public good provision dates back to Oates (1972). However, the "benchmark tax competition model" has been first articulated by Zodrow and Mieszkowski (1986) and Wilson (1986). For surveys on international tax competition literature see Wilson (1999), Wilson and Wildasin (2004) and Haufler (2001).

${ }^{2}$ A large branch of fiscal competition literature assumes that governments finance solely a residential public good that does not affect capital productivity. In these cases even when international fiscal competition takes place via public spending (see e.g. Wildasin 1988) the benchmark results of tax competition theory (i.e. inefficiently low capital tax rates and underprovision of public good) do not change. Fuest (1995) and Bayindir-Upmann (1998) suggest that fundamental tax competition results (i.e. underprovision of public good) may change crucially when public good is assumed to affect directly the productivity of capital. Moreover, when both residential public goods and public inputs are provided, non-cooperative fiscal policy leads to a systematic bias toward public inputs (Keen and Marchand 1997).

${ }^{3}$ The earliest paper in this literature, the study of Case et al. (1993) estimates a model of strategic interaction in expenditures among state government in the U.S. Similar research has been conducted by Baicker (2005) who replicated Case et al. (1993) results by carrying out a similar exercise with different econometric techniques and Murdoch et al. (1993) who estimate a model based on city-level spillovers in recreation expenditures using municipal data. On the taxation side, most of the existing empirical works on reaction function has employed local level data and examine within country strategic interdependence -due to tax competition -among states or provinces. Brueckner and Saavedra (2001), Brett and Pinkse $(1997,2000)$ estimate tax reaction functions focusing on properties taxes for cities in the Boston metropolitan area and Canada respectively. Other empirical studies that rely on tax competition theory are Hayashi and Boadway (2001) focused on provincial corporate income taxes on Canada and Buettner (2001) which carry out a similar exercise using local business tax in Germany. Finally, Pitlik (2007) examines international policy diffusion as a potential source of policy liberalization among OECD economies by employing identical empirical methodology.
} 
tax rates as well as over some categories of public spending (e.g. general public services and education spending).

The present paper contributes to this literature in two ways. First, apart from estimating solely fiscal policy reaction functions we proceed by estimating a foreign direct investment (FDI) inflows equation. This gives us the opportunity to examine directly whether fiscal policy choices home and abroad affect domestic capital inflows and moreover, to illuminate the sign of potential fiscal policy externalities among OECD economies. Second, we study strategic fiscal policy interdependence across national borders by examining not only whether domestic capital tax rates (resp. public investment spending) react to changes in capital tax rates (resp. public investment spending) in neighbouring economies but in addition whether capital tax rates (resp. public investment) react to changes in public investment spending (resp. capital tax rates) abroad. In this way, we place the spotlight on an important issue not previously examined by the relevant literature. This is the potential strategic substitution between capital tax rates and public investment spending. ${ }^{4}$ Our dataset consists of a panel of 20 OECD countries over the period 1982-2000.

Our main empirical findings are as follows. First, we confirm the existence of fiscal policy spillovers among OECD countries. Specifically, we verify that FDI inflows in a country are: (i) negatively related to the difference between domestic capital tax rates and foreign capital tax rates and (ii) positively related to the difference between domestic public investment spending and foreign public investment spending. ${ }^{5}$ Second, we show that domestic capital tax rates react positively to changes in capital tax rates in neighbouring economies. ${ }^{6}$ Third, we empirically evidence that domestic capital tax rates react negatively to changes in public investment spending abroad. Fourth, no empirical evidence of strategic interdependence over public investment spending decisions is established.

\footnotetext{
${ }^{4}$ To our knowledge this is the first study that examines cross instruments strategic interdependence. Previous studies are either focused strictly on tax reactions functions (see e.g. Devereux et al., 2008; Cassette and Paty, 2008) or estimate tax and government spending reaction functions (e.g. Case et al., 1993; Redoano, 2007) without however examining cross instrument fiscal competition.

${ }^{5}$ Our results are consistent with previous empirical studies examining the effect of tax rates on international capital allocation (see e.g. Bénassy-Quéré et al., 2005a; de Mooij and Ederveen 2003; Devereux and Griffith 2003). Concerning the effect of government spending on FDIs, our results are consistent with Bénassy-Quéré et al. (2005b) who argue that particular categories of public spending (such as Infrastructure Spending, Research and Development and Health) do affect international capital location decision.

${ }^{6}$ Our findings are consistent with the theoretical predictions of fiscal competition theory (e.g. Wildasin, 1988; Keen and Marchand, 1997) and the empirical findings of previous studies on OECD economies (e.g. Devereux et al., 2008; Cassette and Paty, 2008; Besley et al., 2001).
} 
The structure of the paper is as follows; in the next section, we present a theoretical framework; in section 3, we discuss the empirical specification and some econometric issues; in section 4, we discuss the data; in section 5 we present the empirical results. Finally, section 6 concludes.

\section{Theoretical Setup}

In this section we describe a standard "resource flow" model (see Brueckner, 2003). Jurisdiction $i$ cares about capital resides within its borders. Because the international distribution of this resource among jurisdictions depends on the fiscal policy choices of all, jurisdiction $i$ is then indirectly affected by fiscal policy abroad.

International capital inflows in country $i$ are given by:

$$
K_{i t}=K\left(P_{i t}, P_{j t} ; X_{i t}\right) \quad i \neq j, \quad j=1,2, \ldots . n
$$

where $K_{i t}$ is international capital inflows in country $i, P_{i t}$ is fiscal policy instruments (taxes or spending) in country $i$ and $P_{j t}$ is fiscal policy instruments in foreign countries. Finally, $X_{i t}$ is a vector of socio-economic characteristics of country $i$.

National government in country $i$ decides $P_{i t}$ in order to maximize the welfare of the representative agent by taking equation (1) into account and $P_{j t}$ as given. This, yield a fiscal policy reaction function that describes country $i$ 's best response to fiscal policy choices abroad. This can be written as:

$$
P_{i t}=R\left(P_{j t} ; X_{i t}\right) \quad i \neq j, \quad j=1,2, \ldots . n
$$

Empirical works on strategic interaction (i.e. Devereux et al., 2006, 2008; Brueckner, 2003; Brueckner and Saavedra, 2001) focus on estimating the slope of the reaction function. Finding a non zero, statistically significant, estimated slope imply existence of strategic behavior among jurisdictions. In addition, an upward (resp. downward) sloping reaction function indicates that fiscal policy instruments $P_{i t}$ and $P_{j t}$ are strategic complements (resp. substitutes). ${ }^{7}$

\footnotetext{
${ }^{7}$ In games with two players, each with only one strategic variable, it is well known that the two variables being strategic complements (resp. substitutes) is equivalent to positively sloped (resp. negatively sloped) reaction functions (see e.g. Fudenberg and Tirole, 1991)
} 
In the presence of spillovers among jurisdictions non-cooperative Nash equilibrium is inefficient since it fails to maximize social welfare. However, equation (2) gives no information about the sign of fiscal policy spillovers and consequently about the direction of the inefficiency (i.e. whether non cooperative (Nash) fiscal policy choices are inefficiently low or inefficiently high). ${ }^{8}$ Apart from that, verifying existence of strategic behavior among jurisdictions does not illuminate the source of interdependence and leaves room to totally different theoretical explanations. ${ }^{9}$

In this paper apart from estimating fiscal policy reaction function we proceed by additionally estimate equation (1). This gives us the opportunity to examine directly whether fiscal policy choices home and abroad affect domestic capital inflows and moreover, to illuminate the sign of fiscal policy externalities. Finding a positive (resp. negative), statistically significant, relation between $P_{j t}$ and $K_{i t}$ implies existence of positive (negative) fiscal policy spillovers among regions. ${ }^{10}$

\section{Empirical Specification}

\subsection{Empirical specification of the capital inflow equation}

Equation (1) implies that international capital inflows in country $i$, depend on fiscal policy chosen at home $\left(P_{i t}\right)$ and abroad $\left(P_{j t}\right)$ as well as country $i$ 's characteristics, represented by a vector $X_{i t}$. In order to obtain a measure of fiscal policy chosen abroad $\left(P_{j t}\right)$, we follow the existing literature (see e.g. Devereux et al., 2006, 2008; Brueckner, 2003) and assume that $P_{j t}$ is a weighted average of fiscal policy chosen in foreign countries. Thus, we have:

\footnotetext{
${ }^{8}$ The standard game theoretic result for symmetric equilibria is that in the presence of positive (resp. negative) externalities, players strategies, are inefficiently low (resp. high) in a Nash equilibrium relative to a cooperative one (see Cooper and John, 1988; Philippopoulos and Economides, 2003).

${ }^{9}$ Although much of the empirical literature concludes that OECD countries do affect each other on the tax setting, the source of interdependence remains yet highly controversial. This is because fiscal strategic interaction among countries may be due to reasons other than tax competition for mobile factors. A widespread alternative theoretical explanation of the detected strategic interaction is the theory of yardstick competition (see e.g. Shleifer, 1985; Salmon, 1987; Besley and Case, 1995). According to this theory citizens compare public services and taxes across jurisdictions in order to judge whether their own political representatives waste resources and deserve to be voted out of office. In the presence of such comparisons, policy makers decide their own fiscal policy by "mimicking" the corresponding fiscal policy in neighbouring economies.

${ }^{10}$ Note the underlying assumption that welfare of the representative agent residing in country $i$ is positively dependent on $K_{i t}$.
} 


$$
\bar{P}_{j t} \equiv \sum_{j \neq i} w_{i j} P_{j t} \quad \text { and } \quad \sum_{j \neq i} w_{i j}=1
$$

where $w_{i j}$ represent nonnegative weights a priori specified. These weights are inversely related to the geographical distance between $i$ and $j$ jurisdiction and capture the relative geographical proximity among two economies (for details, see Appendix A). ${ }^{11}$ In principle, we would like the weights to be large (resp. small) when two states are close (resp. away) from each other.

Assuming that equation (1) is linear and following the relevant empirical literature (i.e. Bénassy-Quéré et al., 2005a; de Mooij and Ederveen, 2003) which suggests that international capital inflows in a country depend on the difference between $P_{i t}$ and $\bar{P}_{j t}$, we estimate the following equation:

$$
K_{i t}=a_{1}\left(P_{i t}-\bar{P}_{j t}\right)+\theta_{1} X_{i t}+f_{i}+\lambda_{t}+u_{i t}
$$

where $a_{1}$ and $\theta_{1}$ are coefficients (theta is vector), $f_{i}$ is country $i$ 's specific fixed effects, $\lambda_{t}$ is country i's specific time effect and $u_{i t}$ is an error term. A positive (resp. negative) $a_{1}$ indicates existence of positive (resp. negative) fiscal policy spillovers.

\subsection{Empirical specification of the policy reaction functions}

Equation (2) implies that fiscal policy in country $i\left(P_{i t}\right)$ depends on country $i$ 's socioeconomic characteristics, represented by a vector $X_{i t}$, and fiscal policy chosen abroad $\left(P_{j t}\right)$. However, equation (2) cannot be estimated as it stands. Although in principle each country could respond differently to the fiscal choices of each other country, this leads to a large number of parameters that cannot be estimated due to lack of degrees of freedom. We follow the relevant literature (see e.g. Devereux et al., 2006, 2008; Brueckner, 2003; Brueckner and Saavedra, 2001) and assume that each country $i$ responds in the same way to the weighted average of fiscal choices of other countries.

\footnotetext{
${ }^{11}$ The methodology we follow in order to construct $w_{i j}$ is identical to that followed by other empirical studies (see e.g. Devereux et al., 2008; Brueckner, 2003; Brueckner and Saavedra, 2001).
} 
This allows us to employ the same weighted average measure $\left(\bar{P}_{j t}\right)$, discussed in the previous section.

Assuming that reactions functions are linear and allowing for country specific fixed effects and time trends (as in Devereux et al., 2008), the associated estimating equation can be written as:

$$
P_{i t}=\beta_{1} \bar{P}_{j t}+\theta_{2} X_{i t}+f_{i}+t_{i t}+u_{i t}
$$

where $\beta_{1}$ and $\theta_{2}$ are coefficients (theta is vector), $f_{i}$ is country $i$ 's specific fixed effect, $t_{i t}$ country $i$ 's specific time trend and $u_{i t}$ is the error term. Finding a non-zero and statistically significant $\beta_{1}$ provides evidence of strategic interaction among regions in fiscal policy instruments.

\subsection{Econometric issues related to the estimation of reaction functions.}

Because of possible strategic interactions, fiscal policy instruments in different jurisdictions are jointly determined. As a result, the $\bar{P}_{j t}$ appearing on the right hand side of (4) is endogenous and correlated with the error term $u_{i t}$. This correlation means that OLS estimators of (4) are inconsistent, requiring the use of an alternative estimation method.

We follow the relevant literature (see e.g. Devereux et al., 2006; 2008) and employ an instrumental variable (IV) approach to address this. For each element of $X_{i t}$, denoted by $x_{i t}$, we construct a weighted average of other countries' corresponded elements: $\bar{X}_{j t}=\sum_{j \neq i} w_{i j} x_{j t}$ and regress $\bar{P}_{j t}$ on $\bar{X}_{j t}$. Then, as a second stage, we regress the predicted variables of $\bar{P}_{j t}$ on $P_{i t}$. Tables report the regression results of the second stage.

A second issue is that in practice, government spending and taxation are serially correlated, perhaps because changes in fiscal policy may have costs of adjustment on the private sector or because such changes may have political cost and tend to be blocked by interest groups. There may also be spatial correlation in the error terms. Spatial error dependence arises when the error term $u_{i t}$ includes omitted variables that are themselves spatially dependent. To deal with the problem of spatial dependence 
we employ the IV estimation method. ${ }^{12}$ In addition, we present t-statistics based on clustered standard errors which are robust to both spatial and serial correlation (see e.g. Bertrand, Duflo and Mullainathan, 2004)

A third issue is that while we would like to include time dummies in order to capture the shocks in each period which are common to all countries, this is not generally feasible. To see this, consider the case of uniform weights. Then (4) can be written as an equation where $P_{i t}$ depends on the average of all countries' fiscal choices $\bar{P}_{t}=\frac{\sum_{j=1}^{n} P_{j t}}{n}$ plus $X_{i t}$. The effect of $\bar{P}_{t}$ has no cross country variation and cannot be identified separately from a time dummy. However, we do allow for unobserved factors varying over time as far as possible by including country specific time trends. We also include country specific fixed effects.

\section{Data}

Our dataset consists of 20 OECD countries for the $1982-2000$ period. ${ }^{13}$ In Tables 1 and 2, we employ as dependent variable the Foreign Direct Investment inwards as a share of GDP (denoted as FDI). Data for FDI are obtained from United Nation Conference on Trade and Development (UNCTAD), Foreign Direct Investment Database.

In Table 1, we estimate equation (3) by focusing on international capital tax rates and examining how the latter affect Foreign Direct Investment allocation. Hence, in this case, the fiscal policy instruments, $P_{i t}$ and $\bar{P}_{j t}$, take the form of capital tax rates home and abroad respectively. More precisely, FDI is regressed on capital tax rate differences between home and abroad (tcap - retcap and tcorp-retcorp) as well as on a set of control variables. ${ }^{14}$

In order to capture the tax burden on capital, we employ two alternative effective tax rate measures constructed by Adam and Kammas (2007) based on the

\footnotetext{
${ }^{12}$ It has been demonstrated that IV yields consistent estimations even in the presence of spatial error dependence (see Kelejian and Prucha, 1998).

${ }^{13}$ The countries in our sample are: Australia, Austria, Belgium, Canada, Denmark, Finland, France, UK, Germany, Greece, Ireland, Italy, Luxembourg, Netherlands, Norway, Portugal, Spain, Sweden, Switzerland and USA.

${ }^{14}$ The weighted average of capital tax rates in neighbouring countries retcorp and retcap are constructed as suggested by Devereux et al. (2008) and Brueckner (2003). For more details on this see section 3.1
} 
methodology developed by Mendoza et al. (1994). ${ }^{15}$ Specifically, we employ: (i) the effective tax rate on corporate profits (denoted as tcorp) which takes into account exclusively the tax burden fallen on corporate profits and (ii) the effective tax rate on capital income (denoted as tcap) which can be viewed as a more general measure of the tax burden on capital. ${ }^{16}$

The other control variables are the standard variables used in the empirical literature on FDIs (see e.g. Bénassy-Quéré et al., 2005a; Devereux and Griffith, 1998). FDI stock (denoted as FDIstock) is the value of foreign direct investment established in the host as a share of the domestic GDP; unit labor costs (unlab) comprise wages, salaries and social security contributions paid by the employer per unit of output; government spending (govspend) is total government spending as a share of GDP; and productivity of labor (prod) is the output per unit of labour input. Finally, market potential (markpot) is measured as a ratio of GDP per capita in the host country to its internal geographical area (for more details on data see Appendix B).

In all the regressions, we include two-way error component fixed effects to account for country- specific and time- specific, unobservable factors.

In Table 2, we estimate equation (3) by focusing on public investment spending and examining how the latter influences international capital allocation. Hence, in this case, fiscal policy instruments $P_{i t}$ and $\bar{P}_{j t}$ take the form of public investment spending at home and abroad respectively. More precisely, in Table 2, FDI is regressed on public investment spending differences between home and abroad ( publinv1-republinv1 and publinv2-republinv2), as well as on the above described set of explanatory variables. ${ }^{17,18}$

\footnotetext{
${ }^{15}$ The simple measures of statutory tax rates cannot capture the complexity of the tax system nor provide a clear indicator of the implied tax policy. Since the overall tax burden does not depend solely on the statutory tax rates, but also on what is defined - by the tax legislation - as the tax base, we are in need of some more complicated tax measures that take into account changes in the tax base (e.g. changes in allowances or deductions). The approach of calculating effective average tax ratios, based on the Mendoza et al. (1994) approach, basically consists of defining the tax rate as a ratio of the tax revenues from a particular tax base to the corresponding tax base (for a critical comparison of alternative effective tax rate methodologies, see e.g. Volkerink and de Haan, 2001)

${ }^{16}$ For more details on the methodology developed by Mendoza et al. (1994) see Appendix A.

${ }^{17}$ The weighted average of public investment spending in neighbouring countries republinv1 and republinv 2 are constructed as suggested by Devereux et al. (2008) and Brueckner (2003). For more details on this see section 3.1

${ }^{18}$ In Table 2 the variable govspend is replaced by the statutory capital tax rate (denoted as statcorp). This is because in Table 2 our main controls of interest (i.e. publinv1 and publinv2) are government spending measures and thus we are in need of some tax rate measure. Data for statcorp are obtained from the World Tax Database from the Office of Tax Policy Research (OTPR) at the University of
} 
In order to capture public investment spending, we employ two alternative measures. The first one (denoted as publinv1) comprises the summation of the "Transport and Communications" and the "General Public Services" accounts whereas the second one (denoted as publinv2) comprises exclusively the "Transport and Communications” account. All data required to construct these variables are taken from the IMF Government Financial Statistics (GFS) dataset.

Finally, we include country and time dummies in our regressions to control for unobserved heterogeneity and common time effects.

In Tables 3 to 5, we proceed by estimating equation (4) (i.e. fiscal policy reaction function). More precisely, in Tables 3 we interchangeably employ as dependent variable tcap and tcorp and we then estimate two alternative reaction functions of capital tax rates. To capture the reaction of domestic capital tax rates to capital tax rates abroad, we follow the existing literature (see e.g. Devereux et al., 2008; Brueckner, 2003) by regressing the predicted values of retcap and retcorp (taken from the first step of the IV method as described in section 3.3) on domestic tax rates tcap and tcorp correspondingly.

Our empirical specification follows Devereux et al., (2008) (hereafter denoted as DLR (2008)). In particular, we employ as control variables the DLR (2008) set of tax rate determinants. Thus, we employ the proportion of population below 14 years old (denoted as young), the proportion of population above 65 years old (old); the proportion of population living in urban areas (urban); public consumption as a share of GDP; market openness to trade (openness) and the relative size of each economy (relsize). ${ }^{19}$ Moreover, we employ the cabinet ideology measure developed by Cusack (1997) (denoted as gov) in order to control for partisan effects on the tax setting (see e.g. Winer and Hettich, 2003; Reed, 2006). This measure locates government ideology on a min-max range with higher values denoting more extreme right-wing government. Finally, we include country-specific dummies and country-specific time trends in our regression to control for unobserved heterogeneity and allow for unobserved factors to vary over time as far as possible. ${ }^{20}$

\footnotetext{
Michigan. OTPR provides extensive tax data compiled from various sources (Price Waterhouse Coopers, Corporate Taxes Worldwide Summaries and Individual Income: Worldwide Summaries and World Bank's Development Indicators).

${ }^{19}$ Relsize is measured as the ratio of domestic GDP to the GDP in USA. Fore more details on relsize see Appendix A and DLR (2008)

${ }^{20}$ Ideally we would like to include time dummies to capture shocks in each period that are common to all countries but this is not generally feasible (See section 3.3 and DLR (2008), footnote 35, pp.1224 on this issue).
} 
In Table 4, we proceed by estimating again capital tax rates' reaction functions. Thus, we employ again as dependent variables tcap and tcorp. However, in this case we extend our set of controls by additionally including two alternative measures of public investment spending in neighboring countries (i.e. republinv1 and republinv2). This allows us to investigate the crucial issue of potential strategic substitution between capital tax rates and public investment spending (i.e. whether domestic capital tax rates also react to changes in public investment spending abroad). Our empirical specification is the identical to that employed in Table 3.

In Table 5, we proceed by estimating public investment spending reaction function. In this case, we interchangeably employ as dependent variable publinv1 and publinv2.

To examine whether public investment spending at home reacts to changes in public investment spending abroad we regress the predicted values of republinv1 and republinv2 (obtained from the first step of IV method as described in section 3.3) on publinv1 and publinv2 correspondingly. Additionally, we regress retcap and retcorp on publinv1 and publinv2 in order to examine whether domestic public investment also reacts to changes in capital tax rates abroad.

Our core set of control variables is based on the studies of Case et al. (1993) (hereafter denoted as CHR (1993)) and Rodrik (1998). Hence, we employ the proportion of population below 14 years old (young); the proportion of population above 65 years old (old); the population density (dens); the fraction of population living in urban areas (urban); GDP per capita (gdppercap); the market openness to international trade (openness). Moreover, we employ the cabinet ideology measure constructed by Cusack (1997) (denoted as gov) in order to control for potential partisan effects on fiscal spending (see e.g. Perotti and Kontopoulos, 2002; Van Dalen and Swank, 1996) and an ethnic tension index (denoted as ethnic) in order to control for the effects of ethnic heterogeneity on government spending (see e.g. Easterly and Levine, 1997; Alesina and Glaeser, 2004). ${ }^{21}$ As before, in all regressions, we include country-specific dummies and country specific time trends to control for unobserved heterogeneity and allow for unobserved factors to vary over time

\footnotetext{
${ }^{21}$ Lower ratings are given to countries where racial and nationality tensions are high because opposing groups are intolerant and unwilling to compromise. Higher ratings are given to countries where tensions are minimal, even though such differences may still exist (for details see ICRG, 2006)
} 


\section{Results}

In the following subsections we discuss the results obtained by working as above. These are reported in Tables 1 to 5.

\subsection{Testing the effect of capital tax rates on Foreign Direct Investment}

We start by testing the FDI equations (3) presented in section 3.1, using the data and the empirical methodology outlined in the previous section. The results are reported in Table 1.

[Table 1 here]

In columns 1 to 5, FDI is regressed on the difference between domestic capital tax rates and foreign capital tax rates (tcap-retcap) as well as on a standard set of control variables (i.e. unlab, prod, FDIstock, govspend and markpot ) in a two-way error component fixed effect specification. As can be seen, the coefficient on capital tax rate differences (tcap-retcap) appears to be negative and highly significant in most of the estimations which implies that FDI inwards are affected negatively (resp. positively) by increases in domestic (resp. foreign) capital tax rates.

As far as the rest of the explanatory variables are concerned, we observe that all of them bear the expected -by the theory-sign. FDIstock and prod enter with positive and significant coefficients, indicating the positive effect of established FDI and increased labor's productivity to the FDI inflows in a country. On the other hand, unlab, markpot and govspend appear to be non significant in all the alternative specifications.

In Columns 6 to 10, we estimate equation (3) by employing the effective tax rate on corporate profits (tcorp) as alternative proxy of capital tax burden. Hence, in this case, FDI is regressed on the difference between domestic corporate profits tax rates and foreign corporate tax rate (tcorp-retcorp) whereas the empirical specification and the set of control variables remain unchanged. As can be seen, our results remain qualitative intact. Capital tax rate difference (tcorp-retcorp) enter with a negative and statistically significant coefficient while the coefficients on FDIstock and prod stay positive and highly significant in all the specifications. A worth noting point is 
that, in this case, unlab bears a negative and statistically significant coefficient implying that FDI inwards are affected negatively by increases in unit labor cost.

Summarizing the main messages of Table 1, we conclude that FDI inflows are negatively (resp. positively) affected by increases in domestic (resp. foreign) capital tax rates. Our results provide empirical support for the existence of positive tax policy spillovers among OECD countries.

\subsection{Testing the effect of public investment on Foreign Direct Investment}

In Table 2 we test the FDI equation (3) presented in section 3.1 by employing the data and the empirical methodology outlined in the previous section. In this case, the fiscal policy instrument under examination is public investment spending.

[Table 2 here]

In columns 1 to 5, FDI is regressed on the difference between domestic public investment spending and public investment spending in neighboring economies ( publinv1-republinv1) and on the standard set of explanatory variables in a two-way error component fixed effect specification. ${ }^{22}$

As can be seen the difference ( publinv1-republinv1) bears a positive and statistically significant coefficient in all the alternative specifications which implies that FDI inwards are affected positively (resp. negatively) by increases in domestic (resp. foreign) public investment spending.

Concerning the rest of the control variables, our results remain qualitative similar to those presented in Table 1. FDIstock and prod enter with positive and significant coefficients whereas the coefficient on statcorp appears to be negative and statistically significant. The only worth noting difference is that, in this empirical specification, the coefficient on markpot becomes significant at a level of 99 percent. The positive effect of markpot on FDI inwards highlights the fact that richer and geographically- smaller economies tend to attract more Foreign Direct Investments.

In columns 6 to 10, we estimate equations (3) by employing publinv2 as alternative measure of public investment spending. As can be verified, our main results remain qualitative the same. Namely, public investment spending difference

\footnotetext{
${ }^{22}$ As we have already mentioned, in Table 2, the core set of explanatory variables remain identical to that of Table 1 . The only difference is that in Table 2 we have replaced the govspend variable with statutory tax rate (denoted as statcorp). For more details on this see Section 4 and footnote 15.
} 
( publinv2 - republinv2) bear positive and statistically significant coefficients in most of the estimations whereas the coefficients on the rest of the explanatory variables remain qualitative intact.

The overall message delivered by Table 2 could be described as follows. FDI inflows are positively (resp. negatively) affected by increases in domestic (resp. foreign) public investment spending which implies negative public investment spending spillovers among OECD economies.

\subsection{Testing strategic interaction in capital tax rates}

In Table 3, we report results from the estimation of fiscal policy reaction function (4) when the key fiscal policy instrument under examination is capital tax rates. More precisely, in columns 1 to 6 , tcap is regressed on the predicted values of retcap and the core set of control variables (i.e old, young, urban, openness, relsize, pcons and gov) following the empirical method described in section 3.3.

[Table 3 here]

As can be seen, the coefficient on retcap appears to be positive and statistically significant at a level of 99 percent which implies that domestic capital tax rates do react positively to changes in capital tax rates in neighbouring economies. This result, remains highly robust through all the alternative specifications providing sound evidence of strategic interdependence in capital tax policy setting across OECD economies. $^{23}$

As far as the rest of the explanatory variables are concerned, our empirical findings appear to be consistent with our theoretical priors as well as the findings of previous empirical studies. In particular, the coefficients on old and pcons are positive and significant, indicating that economies with larger proportion of old population and larger public sectors tend to have increased fiscal needs which in turn may increase capital tax rates. On the other hand, the coefficients on openness and gov bear negative signs and appear to be highly significant in most of the presented estimations. These results are in accordance with our theoretical priors that more open economies tend to rely less on the taxation of mobile factors of production (see e.g.

\footnotetext{
${ }^{23}$ It must be noted that our findings are in line with the findings of previous empirical studies referred to OECD countries (see e.g. Devereux et al., 2008; Besley et al., 2001).
} 
Bucovetsky and Wilson, 1991) as well as that left-wing governments rely heavier on capital taxation (see e.g. Reed, 2006; Bretschger and Hettich, 2002). Moreover, relsize enters with a negative and significant coefficient highlighting that larger economies tend to sustain lower capital tax rates. This result could be attributed to the economies of scale in public good provision of large economies (see e.g. Alesina and Wacziarg, 1997) which in turn implies lower tax burdens. Finally, young appears to be insignificant in most of the presented estimations.

In columns 7 to 12, we employ the effective tax rate on corporate profits (tcorp) as a measure of capital tax rates and re-estimate reaction function (4).Hence, tcorp is now regressed on the predicted values of retcorp whereas the empirical specification and the set of control variables remains unchanged. As can be verified, the coefficient on retcorp bears a positive and significant sign at a level of 99 percent in all alternative estimations. This result is consistent with our previous findings and provides additional evidence of strategic interdependence in capital tax setting among OECD countries. As far as the control variables are concerned, our results remain qualitative intact.

\subsection{Strategic substitution between capital tax rates and public investment spending}

In Table 4, we report results from the estimation of tax policy reaction function (4) when we additionally introduce public investment spending in neighboring economies republinv1 and republinv 2 as explanatory variable. In this way, we place the spotlight on an important issue not previously examined by the relevant empirical literature. This is, the potential strategic substitution between capital tax rates and public investment spending (i.e. whether domestic capital tax rates also react to public investment spending abroad). Providing the fact that international capital location is affected by both capital tax rates and public investment spending (see Tables 1 and 2 for empirical evidence on this), national governments may choose their tax policy rates by taking into account not only the capital tax rates but in addition the public input spending in neighbor economies.

[Table 4 here]

Hence, in columns 1 to 6, tcap is regressed on the predicted values of retcap, the standard set of control variables and additionally on republinv1 and republinv2. 
As can be seen, the coefficients on republinv1 and republinv2 are negative and significant at the level of 99 percent in most of the presented regressions. This implies that governments do take into consideration public input spending abroad, when they decide domestic capital tax rates. Given that increases on public investment spending in neighbor economies motivate capital flights away from the domestic economy, national government react by reducing domestic capital tax rates.

As can be identified, the negative relationship between capital tax rates and public investment spending remains highly robust also in the case where we employ as dependent variable the effective tax rate on corporate profits (tcorp) (columns 7 to 12). As far as the rest of the explanatory variables are concerned, our results remain qualitative similar to those reported in Table 3.

\subsection{Testing strategic interaction in public investment spending}

In Table 5, we report results from the estimation of fiscal policy reaction function when the key fiscal policy instrument under examination is public investment spending. More precisely, in columns 1 to 6, publinv1 is regressed on the predicted values of republinv1 and on a core set of control variables (i.e old, young, ethnic, openness, urban, density, gdppercap, and gov) following the empirical method described in section 3.3. ${ }^{24}$ Moreover, in some regressions we additionally introduce in the set of the controls the retcorp variable and the retcap in order to capture potential strategic substitution between public investment spending and capital tax rates.

[Table 5 here]

As can be seen, in most of the regressions, the coefficient on republinv1 appears to be non significant which implies that domestic public investment spending do not seems to react to changes in public investment spending in neighbouring economies.

As far as the rest of the explanatory variables are concerned, the coefficient on ethnic is positive and significant in most of the regressions indicating that higher

\footnotetext{
${ }^{24}$ Our set of controls consist of standard variables employed in estimation where total government spending enters as dependent variable (see e.g. CHR 1993; Rodrik, 1998). However, it must be stressed that since in our case the dependent variable is not total government spending but a sub-account of it (namely public input spending) there are no clear cut theoretical priors concerning the effects of our controls.
} 
ethnic homogeneity increases public input government spending. ${ }^{25}$ On the other hand, the coefficient on gov is negative and significant at a level of 99 percent in all alternative estimation. This result implies that left-wing governments tend to increase public input government spending. Finally openness, urban, old and density appear to be non significant in most of the presented estimations whereas the coefficient on young and gdppercap bears negative and significant signs.

In columns 7 to 12, we employ as dependent variable the alternative measure of public investment spending, publinv2. Thus, publinv2 is regressed on the predicted values of republinv2 and on a set of control following the empirical method described in section 3.3. Moreover, in some regressions we additionally introduce in the set of the controls the retcorp variable and the retcap in order to capture potential strategic substitution between public investment spending and capital tax rates.

As can be identified, the coefficient on republinv2 appears to be non significant which provides additional evidence that domestic public input spending do not react to changes in public input spending in neighbouring economies. As far as the rest of the explanatory variables are concerned, our results remain qualitative similar to those reported in Columns 1 to 6.

\section{Conclusions}

We examined whether OECD countries compete with each other for mobile factors by using various fiscal (tax-spending) policy instruments. Our dataset consists of a panel of 20 OECD countries over the period 1982-2000.

Our results suggest that international capital inflows (FDI) are affected by fiscal policy at home and abroad. More precisely, there is evidence that international capital inflows (FDI) are negatively (resp. positively) related to capital tax rates (resp. public investment spending) differentials among OECD countries.

Moreover, we show that OECD economies compete via capital tax rates for mobile factors. More precisely, we find that domestic capital tax rates react not only to changes in capital tax rates (as in Devereux et al., 2008; Cassette and Paty, 2008; Besley et al., 2001) but also to changes in public investment spending in neighbouring countries. In this way we provide empirical evidence of strategic substitution between capital tax rates and public investment spending.

\footnotetext{
${ }^{25}$ Easterly and Levine (1997) and Alesina and Glaeser (2004) obtain similar results when they examine the effect of ethnic homogeneity on general government spending.
} 
Appendix A: Variables and Data Sources

\section{Effective Tax Rates}

The methodology of effective taxation basically consists of defining the tax rate as a ratio between the tax revenues from particular taxes and the corresponding tax base. In this paper, we employ data on: (i) the effective tax rate on corporate profits (tcorp) and (ii) the effective tax rate on capital income (tcap) constructed by Adam and Kammas (2007) based on the methodology developed by Mendoza et al. (1994) .

More precisely, based on Mendoza et al. (1994) the tax ratio on corporate profits (tcorp) is defined as the fraction of taxes on income, profits and capital gains of corporations (1200), to the operating surplus of the economy (OS) minus the operating surplus of private unincorporated enterprises (OSPUE). Moreover, the capital income tax ratio (tcap) is defined as the product of personal income tax ratio $\left(t_{p e r}\right)$ and the sum of the operating surplus of private unincorporated enterprises (OSPUE) plus taxes on income, profits and capital gains of corporations (1200) plus taxes on property (4100), and taxes on financial and capital transaction (4400) over the operating surplus of the economy (OS).

\section{Weights in more details}

There are several ways in which a state can assumed to be neighbour of another state. In this paper, we assume that neighbouring is dependent on the geographical proximity between two states. Hence, we construct a weighting matrix that assigns higher values to states geographically close. More in detail: $w_{i j}^{A}=\frac{1}{d_{i j}} / \sum_{j} \frac{1}{d_{i j}}$ where $w_{i j}$ is the $i j$ element of the weighted matrix $W^{d}$ and $d_{i j}$ is the geographical distance between the capital of state $i$ and state $j$. Data on geographical distance among two states are taken from CEPII Geodesic Distance Dataset (2004) 


\begin{tabular}{|c|c|c|c|c|c|c|c|}
\hline & Description & Obs. & Mean & Std.Dev. & $\min$ & $\max$ & Sources \\
\hline tcap & $\begin{array}{l}\text { Effective Average } \\
\text { Tax Rate (EATR) } \\
\quad \text { of capital }\end{array}$ & 334 & 27.796 & 13.530 & 0.140 & 62.590 & $\begin{array}{l}\text { Adam and Kammas (2007) } \\
\text { data based on the } \\
\text { methodology developed by } \\
\text { Mendoza et al. (1994) }\end{array}$ \\
\hline tcorp & $\begin{array}{c}\text { Effective Average } \\
\text { Tax Rate (EATR) } \\
\text { of corporate } \\
\text { profits }\end{array}$ & 315 & 20.642 & 14.268 & 0.070 & 75.230 & $\begin{array}{l}\text { Adam and Kammas (2007) } \\
\text { data based on the } \\
\text { methodology developed by } \\
\text { Mendoza et al. (1994) }\end{array}$ \\
\hline statcorp & $\begin{array}{l}\text { Top corporate } \\
\text { income tax rate }\end{array}$ & 380 & 36.913 & 9.293 & 9.800 & 56.000 & $\begin{array}{l}\text { World Tax Database, Office } \\
\text { of Tax Policy and Research, } \\
\text { University of Michigan }\end{array}$ \\
\hline publinv1 & $\begin{array}{c}\text { Transports, } \\
\text { Communications } \\
\text { and General } \\
\text { Public Services as } \\
\text { a share of GDP }\end{array}$ & 282 & 3.607 & 1.608 & 1.400 & 10.000 & $\begin{array}{c}\text { Author's Calculations based } \\
\text { data taken from IMF, } \\
\text { Government Finance } \\
\text { Statistics Database (2002) }\end{array}$ \\
\hline publinv2 & $\begin{array}{c}\text { Transports and } \\
\text { Communications } \\
\text { as a share of GDP }\end{array}$ & 282 & 1.539 & 1.023 & 0.200 & 5.900 & $\begin{array}{l}\text { Data taken from IMF, } \\
\text { Government Finance } \\
\text { Statistics Database (2002) }\end{array}$ \\
\hline govspend & $\begin{array}{l}\text { Total Public } \\
\text { Spending as a } \\
\text { share of GDP }\end{array}$ & 370 & 36.703 & 8.859 & 19.200 & 55.800 & $\begin{array}{l}\text { World Bank Development } \\
\text { Indicators (2004) }\end{array}$ \\
\hline FDI & $\begin{array}{c}\text { Foreign Direct } \\
\text { Investment } \\
\text { Inwards as a share } \\
\text { of GDP } \\
\end{array}$ & 342 & 1.842 & 3.152 & -1.000 & 28.000 & $\begin{array}{l}\text { United Nation Conference on } \\
\text { Trade and Development } \\
\text { (UNCTAD) Foreign Direct } \\
\text { Investment Database }\end{array}$ \\
\hline FDIstock & $\begin{array}{c}\text { Foreign Direct } \\
\text { Investment Stock } \\
\text { as a share of GDP } \\
\end{array}$ & 342 & 17.982 & 22.941 & 2.000 & 166.000 & $\begin{array}{l}\text { United Nation Conference on } \\
\text { Trade and Development } \\
\text { (UNCTAD) Foreign Direct } \\
\text { Investment Database }\end{array}$ \\
\hline markpot & $\begin{array}{l}\text { GDP per capita to } \\
\text { internal } \\
\text { geographical area }\end{array}$ & 380 & 0.968 & 3.315 & 0.002 & 21.798 & $\begin{array}{l}\text { GDP per capita (constant } \\
1995 \text { US\$) is taken from } \\
\text { WBDI (2004). Internal } \\
\text { geographical area is obtained } \\
\text { from CEPII distance database } \\
\text { (2004) }\end{array}$ \\
\hline prod & $\begin{array}{l}\text { Productivity of } \\
\text { Labour }\end{array}$ & 380 & 85.588 & 9.762 & 53.690 & 100.000 & $\begin{array}{c}\text { OECD Economic Outlook } \\
\text { Dataset (2005a) }\end{array}$ \\
\hline unlab & Unit Labour Costs & 372 & 80.201 & 18.354 & 10.540 & 100.820 & $\begin{array}{c}\text { OECD Economic Outlook } \\
\text { Dataset (2005a) }\end{array}$ \\
\hline openness & $\begin{array}{l}\text { Sum of Imports } \\
\text { and Exports as a } \\
\text { share of GDP }\end{array}$ & 380 & 73.783 & 42.929 & 17.300 & 226.100 & $\begin{array}{l}\text { World Bank Development } \\
\text { Indicators (2004) }\end{array}$ \\
\hline old & $\begin{array}{l}\text { Proportion of } \\
\text { population above } \\
65 \text { years old }\end{array}$ & 380 & 14.087 & 1.897 & 9.700 & 18.070 & $\begin{array}{l}\text { World Bank Development } \\
\text { Indicators (2004) }\end{array}$ \\
\hline young & $\begin{array}{l}\text { Proportion of } \\
\text { population below } \\
14 \text { years old }\end{array}$ & 380 & 19.323 & 2.655 & 14.300 & 30.000 & $\begin{array}{l}\text { World Bank Development } \\
\text { Indicators (2004) }\end{array}$ \\
\hline urban & $\begin{array}{l}\text { Proportion of } \\
\text { population living } \\
\text { in urban areas }\end{array}$ & 380 & 74.763 & 12.802 & 32.500 & 97.300 & $\begin{array}{l}\text { World Bank Development } \\
\text { Indicators (2004) }\end{array}$ \\
\hline gov & $\begin{array}{l}\text { Government } \\
\text { cabinet gravity } \\
\text { indicator. }\end{array}$ & 347 & 2.946 & 0.743 & 2.000 & 4.000 & Cusack (1997) \\
\hline
\end{tabular}




\begin{tabular}{|c|c|c|c|c|c|c|c|}
\hline gdppercap & $\begin{array}{c}\text { GDP per capita } \\
\text { (constant 1995 } \\
\text { US\$) }\end{array}$ & 380 & 24074.77 & 9039.28 & 7329.00 & 56372.00 & $\begin{array}{c}\text { World Bank Development } \\
\text { Indicators (2004) }\end{array}$ \\
\hline ethnic & $\begin{array}{c}\text { Ethnic Tension } \\
\text { Index }\end{array}$ & 318 & 5.216 & 0.919 & 1.000 & 6.000 & $\begin{array}{c}\text { International Country Risk } \\
\text { Guide (ICRG) database } \\
\text { (2006) }\end{array}$ \\
\hline pcons & $\begin{array}{c}\text { Public } \\
\text { Consumption as a } \\
\text { share of GDP }\end{array}$ & 361 & 21.764 & 4.180 & 13.9 & 32.9 & $\begin{array}{c}\text { OECD National Accounts } \\
\text { Database (2005b) }\end{array}$ \\
\hline $\begin{array}{c}\text { Relative size of } \\
\text { each country } \\
\text { measured as } \\
\text { domestic GDP to } \\
\text { the GDP of the } \\
\text { US economy }\end{array}$ & 380 & 10.913 & 21.583 & 0.00 & 100.00 & $\begin{array}{c}\text { GDP Data are obtained from } \\
\text { World Bank Development } \\
\text { Indicators (2004) }\end{array}$ \\
\hline $\begin{array}{c}\text { Population } \\
\text { Density (people } \\
\text { per sq km) }\end{array}$ & 361 & 121.145 & 114.980 & 1.980 & 469.860 & $\begin{array}{c}\text { World Bank Development } \\
\text { Indicators (2004) }\end{array}$ \\
\hline
\end{tabular}




\section{References}

Adam, A., Kammas, P., (2007). Tax policies in a globalized world: Is it politics after all? Public Choice 133, 321-341.

Alesina, A., Glaeser, E., (2004). Fighting poverty in the US and Europe. New York : Oxford University Press.

Alesina, A., Wacziarg, R., (1998). Openness, country size and government. Journal of Public Economics 69, 305-321.

Baicker, K., (2005). The spillover effect of state spending. Journal of Public Economics 89, 529544.

Bayindir-Upmann, T., (1998). Two games of interjurisdictional competition when local governments provide industrial public goods. International Tax and Public Finance 5, 471-487.

Bénassy-Quéré, A., Fontagné, L., Lahrèche-Révil, A., (2005a). How does FDI react to corporate taxation? International Tax and Public Finance 12, 583-603.

Bénassy-Quéré, A., Golbaraja, N., Trannoy, A., (2005b). Tax competition and public input. European Network of Economic Policy Research Institutes Working Paper No.40.

Bertrand, M., Duflo, E., Mullainathan, S., (2004). How much should we trust differences-indifferences estimates? Quarterly Journal of Economics 119, 249-275.

Besley, T., Case, A., (1995). Incumbent behaviour: vote seeking, tax setting and yardstick competition. American Economic Review 85, 25-45.

Besley, T., Griffith, R., Klemm, A., (2001) Empirical evidence on fiscal interdependence in OECD countries. Mimeo.

Bretschger, L., Hettich, F., (2002). Globalization, capital mobility and tax competition : theory and evidence for OECD countries. European Journal of Political Economy 18, 695-716.

Brett, C., Pinkse, J., (1997). Those taxes are all over the map: A test for spatial dependence of municipal tax rates in British Columbia. International Regional Science Review 20, 131-151.

Brett, C., Pinkse, J., (2000). The determinants of municipal tax rates in British Columbia. Canadian Journal of Economics 33, 695-714.

Brueckner, J., (2003). Strategic interaction among governments: An overview of the empirical studies International Regional Science Review 26, 175-188.

Brueckner, J., Saavedra, L., (2001). Do local governments engage in strategic property tax competition? National Tax Journal 54, 203- 229.

Bucovetsky, S., Wilson, J., (1991). Tax competition with two tax instruments. Regional Science and Urban Economics 21, 333-350. 
Buettner, T., (2001). Local business taxation and competition for capital: The choice of the tax rate. Regional Science and Urban Economics 31, 215-245.

Case, A., Hines, J., Rosen, H., (1993). Budget spillovers and fiscal policy interdependence. Journal of Public Economics 52, 285-307.

Cassette, A., Paty, S., (2008). Tax competition among Eastern and Western European countries: With whom do countries compete? Economic Systems 32, 307-325.

CEPII (2004). Geodesic Distances Dataset (http://www.cepii.fr/anglaisgraph/bdd/distances.htm)

Cooper, R., John, A., (1988). Coordinating coordination failures in Keynesian models. Quarterly Journal of Economics 103, 441-463.

Cusack, T., (1997). Partisan politics and public finance: changes in public spending in the industrialized democracies, 1955-1998. Public Choice 91, 375-395.

de Mooij, R., Ederveen, S., (2003). Taxation and foreign direct investment: a synthesis of empirical research. International Tax and Public Finance 10, 673-693.

Devereux, M., Griffith, R., (1998). Taxes and the location of production: evidence from a panel of US multinationals. Journal of Public Economics 68, 335-367.

Devereux, M., Lockwood, B., Redoano, M., (2006). Horizontal and vertical indirect tax competition: Theory and some evidence from the USA. Journal of Public Economics 91, 451479.

Devereux, M., Lockwood, B., Redoano, M., (2008). Do countries compete over corporate tax rates? Journal of Public Economics 92, 1210-1235.

Easterly, W., Levine, R., (1997). Africa's growth tragedy: Policies and ethnic divisions. Quarterly Journal of Economics 111, 1203-1250.

Fuest, C., (1995). Interjurisdictional competition and public expenditure: Is tax coordination counterproductive? Finanzarchiv 52, 478-496.

Fudenberg, D., Tirole, J., (1991). Game Theory. The MIT Press.

Haufler, A., (2001). Taxation in a global economy. Cambridge: Cambridge University Press.

Hayashi, M., Boadway, R., (2001). An empirical analysis of intergovernmental tax interaction: The case of business income taxes in Canada. Canadian Journal of Economics 34, 481-503.

International Country Risk Guide. (2006). IRIS Center, University of Maryland.

Keen, M., Marchand, M., (1997). Fiscal competition and the pattern of public spending. Journal of Public Economics 66, 33-53. 
Kelejian, H., Prucha, I., (1998). A generalized spatial two-stage least squares procedure for estimating a spatial autoregressive model with autoregressive disturbances. Journal of Real Estate Finance and Economics 17, 99-121.

Mendoza, E., Razin, A., Tesar, L., (1994). Effective Tax Rates in macroeconomics: crosscountry estimates of tax rates on factor income and consumption. Journal of Monetary Economics 34, 447-461.

Murdoch, J., Rahmatian, M., Thayer, M., (1993). A spatially autoregressive median voter model of recreation expenditures. Public Finance Quarterly 21, 334-350.

Oates, W.E. (1972). Fiscal federalism. New York: Harcourt Brace Jovanovitch.

OECD, (2005a). Economic outlook: annual and quarterly data. Vol.2005, release 01.

OECD, (2005b). National accounts statistics: annual data main aggregates. Vol.2005.

Perotti, R., Kontopoulos,Y., (2002). Fragmented fiscal policy. Journal of Public Economics 86, 191-222.

Persson, T., Tabellini, G., (1992). The Politics of 1992: Fiscal policy and European integration. Review of Economic Studies 59, 689-701.

Philippopoulos, A., Economides, G., (2003). Are Nash tax rates too low or too high? The role of endogenous growth in models with public goods. Review of Economic Dynamics 6, 37-53.

Pitlik, H., (2007). A race to liberalization? Diffusion of economic policy reform among OECD economies. Public Choice 132, 159-178.

Redoano, M., (2007). Fiscal interaction among European countries. Does the EU matter? CESifo working paper no.1952, Munich.

Reed, R., (2006). Democrats, republicans, and taxes: Evidence that political parties matter. Journal of Public Economics 90, 725-750.

Rodrik, D., (1998). Why do more open economies have bigger governments? The Journal of Political Economy 106, 997-1032.

Salmon, P., (1987). Decentralization as an incentive scheme. Oxford Review of Economic Policy 3, 24-43.

Shleifer, A., (1985). A theory of yardstick competition. Rand Journal of Economics 16, 319-327.

Van Dalen, H., Swank, O., (1996). Government spending cycles: Ideological or opportunistic? Public Choice 80, 183-200.

Volkerink, B., de Haan, J., (2001). Tax ratios: a critical survey. OECD Tax Policy Studies, 1-80. 
Wildasin, D., (1988). Nash equilibria in models of fiscal competition. Journal of Public Economics 35, 229-240.

Wilson, J., (1986). A theory of interregional tax competition. Journal of Urban Economics 19, 296-315.

Wilson, J., (1999). Theories of tax competition. National Tax Journal 52, 269-304.

Wilson, J., Wildasin, D., (2004). Tax competition: bane or boon. Journal of Public Economics 88, 1065-1091.

Winer, S., L., Hettich, W., 2003. The Political Economy of Taxation: Positive and Normative Analysis when Collective Choice Matters. In C. W. Rowley and F. Schneider (eds.), The Encyclopedia of Public Choice. Dordrecht, Netherlands: Kluwer Academic Publishers.

World Bank , (2004). World Bank Development Indicators, CD-ROM, Washington D.C.: World Bank.

Zodrow, G., Mieszkowski, P., (1986). Pigou, Tiebout, property taxation, and the underprovision of local public goods. Journal of Urban Economics 19, 356-370. 
Table 1: The effect of Capital Taxation on FDI Inwards

\begin{tabular}{|c|c|c|c|c|c|c|c|c|c|c|}
\hline Dependent Variable: FDI inwards & (1) & $(2)$ & (3) & (4) & (5) & (6) & (7) & (8) & (9) & $(10)$ \\
\hline tcap - retcap & $\begin{array}{c}-0.043^{*} \\
(-1.77)\end{array}$ & $\begin{array}{c}-0.043^{*} \\
(-1.80)\end{array}$ & $\begin{array}{c}-0.050^{* *} \\
(-2.12)\end{array}$ & $\begin{array}{c}-0.058^{* *} \\
(-2.33)\end{array}$ & $\begin{array}{c}-0.074 * * * \\
(-3.39)\end{array}$ & & & & & \\
\hline tcorp-retcorp & & & & & & $\begin{array}{c}-0.028 * \\
(-1.73)\end{array}$ & $\begin{array}{c}-0.028 * \\
(-1.73)\end{array}$ & $\begin{array}{c}-0.029 * \\
(-1.82)\end{array}$ & $\begin{array}{c}-0.038 * * \\
(-2.28)\end{array}$ & $\begin{array}{c}-0.033 * * \\
(-2.34)\end{array}$ \\
\hline FDIstock & $\begin{array}{c}0.373 * * * \\
(10.21)\end{array}$ & $\begin{array}{c}0.374 * * * \\
(11.05)\end{array}$ & $\begin{array}{c}0.359 * * * \\
(10.00)\end{array}$ & $\begin{array}{c}0.380 * * * \\
(10.03)\end{array}$ & $\begin{array}{c}0.278 * * * \\
(10.98)\end{array}$ & $\begin{array}{c}0.382^{* * *} \\
(10.10)\end{array}$ & $\begin{array}{c}0.386 * * * \\
(11.08)\end{array}$ & $\begin{array}{c}0.362 * * * \\
(9.80)\end{array}$ & $\begin{array}{c}0.385^{* * *} \\
(9.80)\end{array}$ & $\begin{array}{c}0.352 * * * \\
(12.52)\end{array}$ \\
\hline unlab & $\begin{array}{l}-0.027 \\
(-1.36)\end{array}$ & $\begin{array}{l}-0.028 \\
(-1.43)\end{array}$ & & $\begin{array}{l}-0.023 \\
(-1.10)\end{array}$ & $\begin{array}{l}0.014 \\
(0.91)\end{array}$ & $\begin{array}{c}-0.039 * \\
(-1.67)\end{array}$ & $\begin{array}{c}-0.042^{*} \\
(-1.88)\end{array}$ & & $\begin{array}{l}-0.024 \\
(-0.99)\end{array}$ & $\begin{array}{c}-0.048^{* *} \\
(-2.38)\end{array}$ \\
\hline govspend & $\begin{array}{c}3.983 \\
(0.88)\end{array}$ & $\begin{array}{l}3.964 \\
(0.88)\end{array}$ & $\begin{array}{l}0.142 \\
(0.04)\end{array}$ & $\begin{array}{l}6.445 \\
(1.39)\end{array}$ & & $\begin{array}{l}5.012 \\
(1.09)\end{array}$ & $\begin{array}{l}4.932 \\
(1.08)\end{array}$ & $\begin{array}{c}0.921 \\
(0.22\end{array}$ & $\begin{array}{l}7.562 \\
(1.60)\end{array}$ & \\
\hline prod & $\begin{array}{c}0.139 * * * \\
(4.09)\end{array}$ & $\begin{array}{c}0.139 * * * \\
(4.18)\end{array}$ & $\begin{array}{c}0.154^{* * *} \\
(4.88)\end{array}$ & & $\begin{array}{c}0.070 * * \\
(2.27)\end{array}$ & $\begin{array}{c}0.147^{* * *} \\
(4.11)\end{array}$ & $\begin{array}{c}0.146^{* * *} \\
(4.12)\end{array}$ & $\begin{array}{c}0.158^{* * *} \\
(4.83)\end{array}$ & & $\begin{array}{c}0.125^{* * * *} \\
(3.82)\end{array}$ \\
\hline markpot & $\begin{array}{c}0.277 \\
(0.087)\end{array}$ & & $\begin{array}{c}0.660 \\
(0.15)\end{array}$ & $\begin{array}{l}-3.516 \\
(-0.74)\end{array}$ & $\begin{array}{l}6.867 \\
(1.59)\end{array}$ & $\begin{array}{l}1.257 \\
(0.27)\end{array}$ & & $\begin{array}{l}2.558 \\
(0.59)\end{array}$ & $\begin{array}{l}-1.340 \\
(-0.27)\end{array}$ & $\begin{array}{l}3.262 \\
(0.74)\end{array}$ \\
\hline$R^{2}$ & 0.77 & 0.77 & 0.77 & 0.76 & 0.71 & 0.74 & 0.75 & 0.74 & 0.73 & 0.74 \\
\hline Observations & 242 & 242 & 245 & 242 & 307 & 234 & 234 & 237 & 234 & 288 \\
\hline No of countries & 16 & 16 & 16 & 16 & 17 & 15 & 15 & 15 & 15 & 16 \\
\hline
\end{tabular}

(Notes: t-statistics are shown in the parentheses below the estimated coefficients *,**,*** denote statistical significance at $10 \%, 5 \%, 1 \%$.) 
Table 2: The effect of Public Investment Spending on FDI Inwards

\begin{tabular}{|c|c|c|c|c|c|c|c|c|c|c|}
\hline Dependent Variable: FDI inwards & $(1)$ & (2) & (3) & (4) & (5) & (6) & (7) & (8) & (9) & $(10)$ \\
\hline publinv1-republinv1 & $\begin{array}{c}0.383 * * \\
(2.15)\end{array}$ & $\begin{array}{c}0.468 * * \\
(2.58)\end{array}$ & $\begin{array}{c}0.372 * * \\
(2.13)\end{array}$ & $\begin{array}{l}0.308^{*} \\
(1.66)\end{array}$ & $\begin{array}{c}0.393 * * \\
(2.19)\end{array}$ & & & & & \\
\hline publinv2-republinv2 & & & & & & $\begin{array}{c}0.638 * * \\
(2.11)\end{array}$ & $\begin{array}{c}0.786^{* *} \\
(2.55)\end{array}$ & $\begin{array}{c}0.597 * * \\
(2.02)\end{array}$ & $\begin{array}{l}0.402 \\
(1.28)\end{array}$ & $\begin{array}{c}0.620 * * \\
(2.03)\end{array}$ \\
\hline FDIstock & $\begin{array}{c}0.040 * * * \\
(3.95)\end{array}$ & $\begin{array}{c}0.034^{* * *} \\
(3.27)\end{array}$ & $\begin{array}{c}0.040 * * * \\
(3.95)\end{array}$ & $\begin{array}{c}0.021 * * \\
(2.12)\end{array}$ & $\begin{array}{c}0.042 * * * \\
(4.07)\end{array}$ & $\begin{array}{c}0.043^{* * *} \\
(4.22)\end{array}$ & $\begin{array}{c}0.037 * * * \\
(3.58)\end{array}$ & $\begin{array}{c}0.042^{* * *} \\
(4.18)\end{array}$ & $\begin{array}{c}0.022 * * \\
(2.31)\end{array}$ & $\begin{array}{c}0.045^{* * *} \\
(4.35)\end{array}$ \\
\hline unlab & $\begin{array}{l}-0.011 \\
(-0.51)\end{array}$ & $\begin{array}{c}-0.037 * \\
(-1.74)\end{array}$ & & $\begin{array}{l}-0.006 \\
(-0.26)\end{array}$ & $\begin{array}{l}-0.010 \\
(-0.49)\end{array}$ & $\begin{array}{l}-0.015 \\
(-0.72)\end{array}$ & $\begin{array}{c}-0.043^{* *} \\
(-2.02)\end{array}$ & & $\begin{array}{l}-0.009 \\
(-0.39)\end{array}$ & $\begin{array}{l}-0.015 \\
(-0.69)\end{array}$ \\
\hline statcorp & $\begin{array}{c}-0.047 * * \\
(-2.31)\end{array}$ & $\begin{array}{c}-0.049 * * \\
(-2.35)\end{array}$ & $\begin{array}{c}-0.049 * * \\
(-2.49)\end{array}$ & $\begin{array}{c}-0.056 * * * \\
(-2.64)\end{array}$ & & $\begin{array}{c}-0.049 * * \\
(-2.41)\end{array}$ & $\begin{array}{c}-0.052^{* *} \\
(-2.47)\end{array}$ & $\begin{array}{c}-0.051^{* *} \\
(-2.58)\end{array}$ & $\begin{array}{c}-0.058 * * * \\
(-2.71)\end{array}$ & \\
\hline prod & $\begin{array}{c}0.179 * * * \\
(4.84)\end{array}$ & $\begin{array}{c}0.165^{* * *} \\
(4.36)\end{array}$ & $\begin{array}{c}0.184^{* * *} \\
(5.26)\end{array}$ & & $\begin{array}{c}0.187 * * * \\
(5.03)\end{array}$ & $\begin{array}{c}0.184^{* * *} \\
(4.94)\end{array}$ & $\begin{array}{c}0.171^{* * *} \\
(4.49)\end{array}$ & $\begin{array}{c}0.188^{* * *} \\
(4.16)\end{array}$ & & $\begin{array}{c}0.192^{* * *} \\
(5.12)\end{array}$ \\
\hline markpot & $\begin{array}{c}17.025 * * * \\
(3.68)\end{array}$ & & $\begin{array}{c}17.231^{* * *} \\
(4.06)\end{array}$ & $\begin{array}{c}14.706^{* * *} \\
(3.04)\end{array}$ & $\begin{array}{c}17.337 * * * \\
(3.71)\end{array}$ & $\begin{array}{c}17.005^{* * *} \\
(3.67)\end{array}$ & & $\begin{array}{c}17.564^{* * *} \\
(4.16)\end{array}$ & $\begin{array}{c}14.884 * * * \\
(3.07)\end{array}$ & $\begin{array}{c}17.401^{* * * *} \\
\quad(3.72)\end{array}$ \\
\hline$R^{2}$ & 0.64 & 0.62 & 0.64 & 0.60 & 0.63 & 0.64 & 0.62 & 0.64 & 0.60 & 0.63 \\
\hline Observations & 258 & 258 & 261 & 258 & 258 & 258 & 258 & 261 & 258 & 258 \\
\hline No of countries & 17 & 17 & 17 & 17 & 17 & 17 & 17 & 17 & 17 & 17 \\
\hline
\end{tabular}

(Notes: t-statistics are shown in the parentheses below the estimated coefficients *,**,*** denote statistical significance at 10\%, 5\%, 1\%.) 
Table 3: Capital tax rates strategic interaction

\begin{tabular}{|c|c|c|c|c|c|c|c|c|c|c|c|c|}
\hline & \multicolumn{6}{|c|}{ tcap } & \multicolumn{6}{|c|}{ tcorp } \\
\hline & (1) & (2) & (3) & (4) & (5) & (6) & (7) & (8) & (9) & (10) & (11) & (12) \\
\hline retcap & $\begin{array}{c}2.090^{* * *} \\
(4.24)\end{array}$ & $\begin{array}{c}2.331^{* * *} \\
(4.22)\end{array}$ & $\begin{array}{c}2.727 * * * \\
(3.27)\end{array}$ & $\begin{array}{c}1.879 * * * \\
(4.20)\end{array}$ & $\begin{array}{c}1.824^{* * *} \\
(4.86)\end{array}$ & $\begin{array}{c}2.568 * * * \\
(3.50)\end{array}$ & & & & & & \\
\hline retcorp & & & & & & & $\begin{array}{c}2.252^{* * *} \\
(5.21)\end{array}$ & $\begin{array}{c}2.493^{* * *} * \\
(5.22)\end{array}$ & $\begin{array}{c}3.125^{* * *} \\
(4.38)\end{array}$ & $\begin{array}{c}2.094^{* * *} \\
(5.00)\end{array}$ & $\begin{array}{c}2.191^{* * *} \\
(5.06)\end{array}$ & $\begin{array}{c}2.434^{* * *} \\
(3.62)\end{array}$ \\
\hline old & $\begin{array}{c}2.594^{* * *} \\
(3.24)\end{array}$ & & $\begin{array}{l}1.836^{*} \\
(1.89)\end{array}$ & $\begin{array}{c}2.743^{* * * *} \\
\quad(4.40)\end{array}$ & $\begin{array}{c}3.023^{* * *} \\
(3.84)\end{array}$ & $\begin{array}{c}2.491^{* *} \\
(2.85)\end{array}$ & $\begin{array}{c}4.163^{* *} \\
(2.86)\end{array}$ & & $\begin{array}{l}2.376 \\
(1.35)\end{array}$ & $\begin{array}{c}2.707^{*} \\
(1.91)\end{array}$ & $\begin{array}{c}4.636^{* * * *} \\
(3.37)\end{array}$ & $\begin{array}{c}5.230 * * * \\
(3.69)\end{array}$ \\
\hline young & $\begin{array}{l}-0.493 \\
(-0.65)\end{array}$ & $\begin{array}{l}-1.228 \\
(-1.57)\end{array}$ & $\begin{array}{l}-0.998 \\
(-1.08)\end{array}$ & $\begin{array}{l}-0.283 \\
(-0.47)\end{array}$ & $\begin{array}{c}-1.454^{*} \\
(-2.06)\end{array}$ & & $\begin{array}{l}-1.937 \\
(-1.41)\end{array}$ & $\begin{array}{c}-3.166 * * \\
(-2.27)\end{array}$ & $\begin{array}{c}-3.528 * * \\
(-2.15)\end{array}$ & $\begin{array}{c}-2.366^{* *} \\
(-2.18)\end{array}$ & $\begin{array}{c}-3.293^{* *} \\
(-2.51)\end{array}$ & \\
\hline urban & $\begin{array}{c}4.778^{* * *} \\
(3.41)\end{array}$ & $\begin{array}{c}4.792^{* * *} \\
(3.35)\end{array}$ & & $\begin{array}{l}0.996^{*} \\
(1.83)\end{array}$ & $\begin{array}{c}3.930^{* * *} \\
(3.70)\end{array}$ & $\begin{array}{c}5.051^{* * *} \\
(3.46)\end{array}$ & $\begin{array}{c}7.337 * * * \\
(5.51)\end{array}$ & $\begin{array}{c}7.033^{* * *} \\
(4.98)\end{array}$ & & $\begin{array}{c}1.412^{* *} \\
(2.34)\end{array}$ & $\begin{array}{c}6.550 * * * \\
(5.08)\end{array}$ & $\begin{array}{c}7.708 * * * \\
(5.33)\end{array}$ \\
\hline openness & $\begin{array}{c}-0.162 * * * \\
(-4.49)\end{array}$ & $\begin{array}{c}-0.150^{* * *} \\
(-4.06)\end{array}$ & $\begin{array}{c}-0.138 * * * \\
(-3.85)\end{array}$ & $\begin{array}{c}-0.175^{* * *} \\
(-4.84)\end{array}$ & $\begin{array}{c}-0.116^{* * *} \\
(-3.63)\end{array}$ & $\begin{array}{c}-0.197 * * * \\
(-4.47)\end{array}$ & $\begin{array}{c}-0.186^{* *} \\
(-2.66)\end{array}$ & $\begin{array}{c}-0.189 * * \\
(-2.81)\end{array}$ & $\begin{array}{c}-0.206 * * \\
(-2.64)\end{array}$ & $\begin{array}{c}-0.167^{* *} \\
(-2.74)\end{array}$ & $\begin{array}{c}-0.163^{* *} \\
(-2.86)\end{array}$ & $\begin{array}{c}-0.262^{* * *} \\
(-3.19)\end{array}$ \\
\hline relsize & $\begin{array}{c}-0.285 * * * \\
(-3.37)\end{array}$ & $\begin{array}{c}-0.272^{* * *} \\
(-3.10)\end{array}$ & $\begin{array}{c}-0.225^{* *} \\
(-2.28)\end{array}$ & $\begin{array}{c}-0.313 * * * \\
(-3.69)\end{array}$ & $\begin{array}{c}-0.205 * * * \\
(-3.02)\end{array}$ & $\begin{array}{c}-0.279 * * \\
(-2.54)\end{array}$ & $\begin{array}{l}-0.122 \\
(-0.86)\end{array}$ & $\begin{array}{l}-0.121 \\
(-0.75)\end{array}$ & $\begin{array}{l}-0.025 \\
(-0.16)\end{array}$ & $\begin{array}{l}-0.133 \\
(-1.04)\end{array}$ & $\begin{array}{l}-0.049 \\
(-0.40)\end{array}$ & $\begin{array}{l}-0.138 \\
(-0.78)\end{array}$ \\
\hline pcons & $\begin{array}{c}0.868^{* * *} \\
(3.60)\end{array}$ & $\begin{array}{c}1.040^{* * *} \\
(4.28)\end{array}$ & $\begin{array}{c}0.767 * * * \\
(3.94)\end{array}$ & & $\begin{array}{c}0.919 * * * \\
(-3.02)\end{array}$ & $\begin{array}{c}0.838^{* * *} \\
(3.27)\end{array}$ & $\begin{array}{c}0.827^{* * *} \\
(3.04)\end{array}$ & $\begin{array}{c}0.979 * * * \\
(3.63)\end{array}$ & $\begin{array}{c}0.631^{* *} \\
(2.23)\end{array}$ & & $\begin{array}{c}0.980^{* * *} \\
(3.54)\end{array}$ & $\begin{array}{c}0.606^{* * *} \\
(2.91)\end{array}$ \\
\hline gov & $\begin{array}{c}-0.764^{* *} \\
(-1.98)\end{array}$ & $\begin{array}{c}-0.927^{* * *} \\
(-2.41)\end{array}$ & $\begin{array}{c}-0.821^{* *} \\
(-2.08)\end{array}$ & $\begin{array}{c}-0.709 * * \\
(-2.15)\end{array}$ & & $\begin{array}{c}-0.811^{*} \\
(-1.95)\end{array}$ & $\begin{array}{c}-1.492^{* *} \\
(-2.48)\end{array}$ & $\begin{array}{c}-1.547 * * \\
(-2.38)\end{array}$ & $\begin{array}{c}-1.430 * * \\
(-2.21)\end{array}$ & $\begin{array}{c}-1.413^{* *} \\
(-2.43)\end{array}$ & & $\begin{array}{c}-1.553 * * \\
(-2.46)\end{array}$ \\
\hline$R^{2}$ & 0.94 & 0.94 & 0.93 & 0.85 & 0.94 & 0.93 & 0.88 & 0.88 & 0.85 & 0.89 & 0.88 & 0.88 \\
\hline Observations & 301 & 301 & 301 & 320 & 315 & 301 & 282 & 282 & 282 & 301 & 286 & 282 \\
\hline
\end{tabular}

(Notes: t-statistics are shown in the parentheses below the estimated coefficients.*,**,*** denote statistical significance at $10 \%$, 5\%, 1\%.) 
Table 4: Strategic substitution between capital tax rates and public investment spending

\begin{tabular}{|c|c|c|c|c|c|c|c|c|c|c|c|c|}
\hline & \multicolumn{6}{|c|}{ tcap } & \multicolumn{6}{|c|}{ tcorp } \\
\hline & (1) & (2) & (3) & (4) & (5) & (6) & (7) & (8) & (9) & (10) & (11) & (12) \\
\hline retcap & $\begin{array}{c}0.858)^{* * *} \\
\quad(2.93)\end{array}$ & $\begin{array}{c}1.087^{* * *} \\
(3.37)\end{array}$ & $\begin{array}{c}1.390^{* * *} \\
(4.78)\end{array}$ & $\begin{array}{c}1.481^{* * *} \\
(4.90)\end{array}$ & $\begin{array}{c}0.744^{* *} \\
(2.62)\end{array}$ & $\begin{array}{c}1.026^{* * *} \\
(3.44)\end{array}$ & & & & & & \\
\hline retcorp & & & & & & & $\begin{array}{c}1.114^{* * * *} \\
(3.59)\end{array}$ & $\begin{array}{c}1.440 * * * \\
(4.44)\end{array}$ & $\begin{array}{c}1.049 * * * \\
(3.76)\end{array}$ & $\begin{array}{c}1.265^{* * *} \\
(4.56)\end{array}$ & $\begin{array}{c}1.575^{* * *} \\
(4.66)\end{array}$ & $\begin{array}{c}1.829 * * * \\
(5.00)\end{array}$ \\
\hline republinv1 & $\begin{array}{c}-2.949 * * * \\
(-4.00)\end{array}$ & & $\begin{array}{c}-1.321^{* *} \\
(-2.27)\end{array}$ & & $\begin{array}{c}-2.650 * * * \\
(-3.40)\end{array}$ & & $\begin{array}{c}-3.168 * * * \\
(-3.97)\end{array}$ & & $\begin{array}{c}-2.460 * * * \\
(-3.42)\end{array}$ & & $\begin{array}{c}-1.580 * * \\
(-2.17)\end{array}$ & \\
\hline republinv2 & & $\begin{array}{c}-5.698 * * * \\
(-3.68)\end{array}$ & & $\begin{array}{c}-2.737 * * \\
(-2.27)\end{array}$ & & $\begin{array}{c}-4.655^{* * *} \\
(-3.21)\end{array}$ & & $\begin{array}{c}-5.302 * * * \\
(-3.77)\end{array}$ & & $\begin{array}{c}-4.383 * * * \\
(-3.23)\end{array}$ & & $\begin{array}{c}-1.945^{*} \\
(-1.73)\end{array}$ \\
\hline old & $\begin{array}{c}3.629 * * * \\
(5.57)\end{array}$ & $\begin{array}{c}3.622 * * * \\
(5.35)\end{array}$ & $\begin{array}{c}2.655^{* *} \\
(3.99)\end{array}$ & $\begin{array}{c}2.677 * * * \\
(3.93)\end{array}$ & $\begin{array}{c}3.748 * * * \\
(5.94)\end{array}$ & $\begin{array}{c}3.698 * * * \\
(5.60)\end{array}$ & $\begin{array}{c}5.703 * * * \\
(4.39)\end{array}$ & $\begin{array}{c}5.489 * * * \\
(3.99)\end{array}$ & $\begin{array}{c}5.389 * * * \\
(4.02)\end{array}$ & $\begin{array}{c}5.299 * * * \\
(3.77)\end{array}$ & $\begin{array}{c}5.283^{* * *} \\
(4.36)\end{array}$ & $\begin{array}{c}5.074 * * * \\
(3.95)\end{array}$ \\
\hline young & $\begin{array}{l}0.431 \\
(0.57)\end{array}$ & $\begin{array}{l}0.549 \\
(0.69)\end{array}$ & $\begin{array}{l}-1.009 \\
(-1.72)\end{array}$ & $\begin{array}{l}-0.909 \\
(-1.49)\end{array}$ & $\begin{array}{l}-0.737 \\
(-1.23)\end{array}$ & $\begin{array}{l}-0.736 \\
(-1.12)\end{array}$ & $\begin{array}{l}0.045 \\
(0.03)\end{array}$ & $\begin{array}{l}-0.246 \\
(-0.18)\end{array}$ & $\begin{array}{l}-0.844 \\
(-0.70)\end{array}$ & $\begin{array}{l}-0.958 \\
(-0.76)\end{array}$ & $\begin{array}{c}-2.441^{*} \\
(-2.04)\end{array}$ & $\begin{array}{c}-2.716 * * \\
(-2.19)\end{array}$ \\
\hline urban & $\begin{array}{c}5.183^{* * *} \\
(4.49)\end{array}$ & $\begin{array}{c}5.292 * * * \\
(4.27)\end{array}$ & $\begin{array}{c}4.053^{* * *} \\
(2.99)\end{array}$ & $\begin{array}{c}4.146 * * * \\
(2.96)\end{array}$ & $\begin{array}{c}4.368 * * * \\
(4.73)\end{array}$ & $\begin{array}{c}4.406^{* * *} \\
(4.45)\end{array}$ & $\begin{array}{c}8.092^{* * *} \\
(6.02)\end{array}$ & $\begin{array}{c}8.069 * * * \\
(5.77)\end{array}$ & $\begin{array}{c}7.131^{* * *} \\
(5.21)\end{array}$ & $\begin{array}{c}7.176^{* * *} \\
(5.02)\end{array}$ & $\begin{array}{c}6.878 * * * \\
(5.37)\end{array}$ & $\begin{array}{c}6.788^{* * * *} \\
(5.22)\end{array}$ \\
\hline openness & $\begin{array}{c}-0.249 * * * \\
(-5.83)\end{array}$ & $\begin{array}{c}-0.233^{* * *} \\
(-5.35)\end{array}$ & & & $\begin{array}{c}-0.182 * * * \\
(-6.36)\end{array}$ & $\begin{array}{c}-0.162 * * * \\
(-5.34)\end{array}$ & $\begin{array}{c}-0.215^{* * *} \\
(-3.11)\end{array}$ & $\begin{array}{c}-0.205^{* * *} \\
(-2.95)\end{array}$ & & & $\begin{array}{c}-0.159 * * * \\
(-2.97)\end{array}$ & $\begin{array}{c}-0.155^{* *} \\
(-2.90)\end{array}$ \\
\hline relsize & $\begin{array}{c}-0.265 * * \\
(-2.71)\end{array}$ & $\begin{array}{c}-0.335 * * * \\
(-3.36)\end{array}$ & $\begin{array}{l}-0.011 \\
(-0.14)\end{array}$ & $\begin{array}{l}-0.050 \\
(-0.61)\end{array}$ & $\begin{array}{l}-0.166 \\
(-1.88)\end{array}$ & $\begin{array}{c}-0.225^{* *} \\
(-2.70)\end{array}$ & $\begin{array}{l}-0.122 \\
(-0.85)\end{array}$ & $\begin{array}{l}-0.184 \\
(-1.24)\end{array}$ & $\begin{array}{l}0.107 \\
(0.74)\end{array}$ & $\begin{array}{l}0.047 \\
(0.32)\end{array}$ & $\begin{array}{l}-0.023 \\
(-0.18)\end{array}$ & $\begin{array}{l}-0.057 \\
(-0.44)\end{array}$ \\
\hline pcons & $\begin{array}{c}0.932 * * * \\
(3.82)\end{array}$ & $\begin{array}{c}-0.335 * * * \\
(-3.36)\end{array}$ & $\begin{array}{c}1.186^{* * *} \\
(4.45)\end{array}$ & $\begin{array}{c}1.196 * * * \\
(4.51)\end{array}$ & $\begin{array}{c}1.013^{* * *} \\
(4.33)\end{array}$ & $\begin{array}{c}1.023^{* * *} \\
(4.48)\end{array}$ & $\begin{array}{c}0.923 * * * \\
(3.26)\end{array}$ & $\begin{array}{c}0.936^{* * * *} \\
(3.41)\end{array}$ & $\begin{array}{c}1.155^{* * *} \\
(3.53)\end{array}$ & $\begin{array}{c}1.160 * * * \\
(3.63)\end{array}$ & $\begin{array}{c}1.062 * * * \\
(3.53)\end{array}$ & $\begin{array}{c}1.033^{* * * *} \\
(3.48)\end{array}$ \\
\hline gov & $\begin{array}{c}-0.772 * * \\
(-2.35)\end{array}$ & $\begin{array}{c}-0.830 * * \\
(-2.29)\end{array}$ & $\begin{array}{c}-0.751^{* *} \\
(-2.23)\end{array}$ & $\begin{array}{c}-0.781^{* *} \\
(-2.19) \\
\end{array}$ & & & $\begin{array}{c}-1.542 * * * \\
(-3.05)\end{array}$ & $\begin{array}{l}-1.583 \\
(-2.93) \\
\end{array}$ & $\begin{array}{c}-1.537 * * * \\
(-3.10)\end{array}$ & $\begin{array}{c}-1.573 * * * \\
(-3.04)\end{array}$ & & \\
\hline$R^{2}$ & 0.95 & 0.95 & 0.94 & 0.95 & 0.95 & 0.95 & 0.91 & 0.91 & 0.90 & 0.91 & 0.90 & 0.89 \\
\hline Observations & 301 & 301 & 301 & 301 & 315 & 315 & 282 & 282 & 282 & 282 & 296 & 296 \\
\hline
\end{tabular}

(Notes: t-statistics are shown in the parentheses below the estimated coefficients.*,**,*** denote statistical significance at $10 \%$, 5\%, 1\%.) 
Table 5: Public investment spending strategic interaction

\begin{tabular}{|c|c|c|c|c|c|c|c|c|c|c|c|c|}
\hline & \multicolumn{6}{|c|}{ publinv1 } & \multicolumn{6}{|c|}{ publinv2 } \\
\hline & (1) & (2) & (3) & (4) & (5) & (6) & (7) & (8) & (9) & (10) & $(11)$ & (12) \\
\hline republinv1 & $\begin{array}{l}0.085 \\
(1.30)\end{array}$ & $\begin{array}{l}0.122 \\
(1.53)\end{array}$ & $\begin{array}{c}0.128 * \\
(1.94)\end{array}$ & $\begin{array}{l}0.042 \\
(0.74)\end{array}$ & $\begin{array}{l}0.053 \\
(0.75)\end{array}$ & $\begin{array}{l}0.068 \\
(1.10)\end{array}$ & & & & & & \\
\hline republinv2 & & & & & & & $\begin{array}{c}0.099 \\
(1.71)\end{array}$ & $\begin{array}{l}0.105 \\
(1.16)\end{array}$ & $\begin{array}{l}0.107 \\
(1.62)\end{array}$ & $\begin{array}{l}0.079 \\
(1.71)\end{array}$ & $\begin{array}{l}0.026 \\
(0.44)\end{array}$ & $\begin{array}{c}0.058 \\
(1.11)\end{array}$ \\
\hline retcorp & & $\begin{array}{l}0.011 \\
(0.72)\end{array}$ & & & $\begin{array}{l}-0.001 \\
(-0.08)\end{array}$ & & & $\begin{array}{l}-0.001 \\
(-0.01)\end{array}$ & & & $\begin{array}{l}-0.013 \\
(-1.43)\end{array}$ & \\
\hline retcap & & & $\begin{array}{c}0.035 * * \\
(2.39)\end{array}$ & & & $\begin{array}{l}0.021^{*} \\
(1.88)\end{array}$ & & & $\begin{array}{l}0.001 \\
(0.20)\end{array}$ & & & $\begin{array}{l}-0.010 \\
(-1.38)\end{array}$ \\
\hline old & $\begin{array}{l}-0.178 \\
(-1.17)\end{array}$ & $\begin{array}{l}-0.177 \\
(-1.18)\end{array}$ & $\begin{array}{l}-0.212 \\
(-1.35)\end{array}$ & & & & $\begin{array}{l}-0.109 \\
(-0.99)\end{array}$ & $\begin{array}{l}-0.108 \\
(-0.98)\end{array}$ & $\begin{array}{l}-0.110 \\
(-0.99)\end{array}$ & & & \\
\hline young & $\begin{array}{c}-0.151^{* *} \\
(-2.38)\end{array}$ & $\begin{array}{c}-0.163^{* *} \\
(-2.60)\end{array}$ & $\begin{array}{c}-0.168^{* *} \\
(-2.52)\end{array}$ & & & & $\begin{array}{c}-0.130^{* * *} \\
(-3.94)\end{array}$ & $\begin{array}{c}-0.130 * * * \\
(-3.84)\end{array}$ & $\begin{array}{c}-0.131^{* * *} \\
(-3.85)\end{array}$ & & & \\
\hline ethnic & $\begin{array}{l}0.079 * \\
(1.93)\end{array}$ & $\begin{array}{c}0.076^{*} \\
(1.83)\end{array}$ & $\begin{array}{l}0.080 * \\
(1.92)\end{array}$ & & & & $\begin{array}{l}0.027 \\
(1.16)\end{array}$ & $\begin{array}{l}0.027 \\
(1.14)\end{array}$ & $\begin{array}{l}0.027 \\
(1.14)\end{array}$ & & & \\
\hline openness & $\begin{array}{l}0.004 \\
(0.92)\end{array}$ & $\begin{array}{l}0.004 \\
(0.88)\end{array}$ & $\begin{array}{l}0.005 \\
(1.15)\end{array}$ & & & & $\begin{array}{l}0.001 \\
(0.46)\end{array}$ & $\begin{array}{l}0.001 \\
(0.52)\end{array}$ & $\begin{array}{l}0.001 \\
(0.49)\end{array}$ & & & \\
\hline urban & $\begin{array}{l}-0.054 \\
(-1.02)\end{array}$ & $\begin{array}{l}-0.055 \\
(-1.05)\end{array}$ & $\begin{array}{l}-0.047 \\
(-0.93)\end{array}$ & $\begin{array}{l}-0.039 \\
(-0.94)\end{array}$ & $\begin{array}{l}-0.039 \\
(-0.95)\end{array}$ & $\begin{array}{l}-0.031 \\
(-0.74)\end{array}$ & $\begin{array}{c}-0.088^{* * *} \\
(-3.26)\end{array}$ & $\begin{array}{c}-0.088^{* * *} \\
(-3.22)\end{array}$ & $\begin{array}{c}-0.088^{* * *} \\
(-3.22)\end{array}$ & $\begin{array}{c}-0.069 * * \\
(-2.50)\end{array}$ & $\begin{array}{c}-0.070 * * \\
(-2.77)\end{array}$ & $\begin{array}{c}-0.073^{* *} \\
(-2.77)\end{array}$ \\
\hline dens & $\begin{array}{l}0.041 \\
(1.56)\end{array}$ & $\begin{array}{l}0.036 \\
(1.31)\end{array}$ & $\begin{array}{c}0.041 \\
(1.54)\end{array}$ & $\begin{array}{l}0.021 \\
(1.11)\end{array}$ & $\begin{array}{l}0.021 \\
(0.96)\end{array}$ & $\begin{array}{l}0.020 \\
(0.98)\end{array}$ & $\begin{array}{c}0.044^{* * *} \\
(3.59)\end{array}$ & $\begin{array}{c}0.044^{* * *} \\
(3.34)\end{array}$ & $\begin{array}{c}0.044^{* * *} \\
(3.56)\end{array}$ & $\begin{array}{l}0.018 \\
(1.51)\end{array}$ & $\begin{array}{c}0.025^{*} \\
(2.05)\end{array}$ & $\begin{array}{l}0.019 \\
(1.61)\end{array}$ \\
\hline gdppercap & $\begin{array}{c}-0.001 * * \\
(-2.84)\end{array}$ & $\begin{array}{c}-0.001^{* *} \\
(-2.90)\end{array}$ & $\begin{array}{c}-0.001^{* *} \\
(-3.04)\end{array}$ & $\begin{array}{c}-0.001^{* * *} \\
(-2.30)\end{array}$ & $\begin{array}{c}-0.001^{* *} \\
(-2.23)\end{array}$ & $\begin{array}{c}-0.001^{* *} \\
(-2.36)\end{array}$ & $\begin{array}{c}-0.001^{* * *} \\
(-5.95)\end{array}$ & $\begin{array}{c}-0.001 * * * \\
(-5.89)\end{array}$ & $\begin{array}{c}-0.001 * * * \\
(-5.93)\end{array}$ & $\begin{array}{c}-0.001 * * * \\
(-4.79)\end{array}$ & $\begin{array}{c}-0.001^{* * *} \\
(-4.60)\end{array}$ & $\begin{array}{c}-0.001^{* * *} \\
(-4.66)\end{array}$ \\
\hline gov & $\begin{array}{c}-0.118 * * * \\
(-3.73)\end{array}$ & $\begin{array}{c}-0.120 * * * \\
(-3.92)\end{array}$ & $\begin{array}{c}-0.124 * * * \\
(-3.99)\end{array}$ & $\begin{array}{c}-0.116^{* * *} \\
(-3.72)\end{array}$ & $\begin{array}{c}-0.116^{* * *} \\
(-3.85)\end{array}$ & $\begin{array}{c}-0.120 * * * \\
(-3.95)\end{array}$ & $\begin{array}{c}-0.046^{* * *} \\
(-3.00)\end{array}$ & $\begin{array}{c}-0.046^{* *} \\
(-2.89)\end{array}$ & $\begin{array}{c}-0.047 * * \\
(-2.94)\end{array}$ & $\begin{array}{c}-0.044^{* *} \\
(-2.23)\end{array}$ & $\begin{array}{c}-0.041^{* *} \\
(-2.17)\end{array}$ & $\begin{array}{c}-0.042^{* *} \\
(-2.16)\end{array}$ \\
\hline$R^{2}$ & 0.94 & 0.93 & 0.94 & 0.93 & 0.94 & 0.94 & 0.95 & 0.95 & 0.95 & 0.95 & 0.95 & 0.95 \\
\hline Observations & 246 & 246 & 246 & 263 & 263 & 263 & 246 & 246 & 246 & 263 & 263 & 263 \\
\hline
\end{tabular}

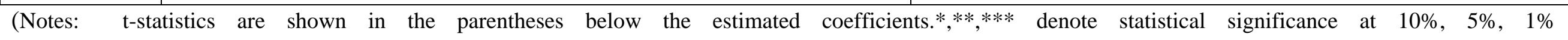


